\title{
Ocula ${ }^{25}$
}

Occhio semiotico sui media | Semiotic eye on media

www.ocula.it • ISSN 1724-7810 • Vol 22, No 25 (June 2021) • DOI: 10.12977/ocula2021-8

Genere, generi e generazioni

Per una riflessione sociologica sui cambiamenti degli stili di consumo

nel mondo globalizzato: scenari attuali e prospettive future

a cura di Piergiorgio Degli Esposti, Antonella Mascio, Geraldina Roberti

\section{Disruptive Tides \\ Feminist Counter-discourse as Resistance to Patriarchal Imagery in Gendered Media Representations}

\author{
Maria Chiara Caiazzo \\ Universitat Pompeu Fabra, Barcelona, SP \\ King's College, London, UK \\ mchiaracaiazzo@gmail.com
}

\begin{abstract}
This paper examines women's self-determination within patriarchal discursive regimes, specifically in the cultural texts produced by the fashion industry. In westernized capitalist consumer societies, women's gender identity is structured according to oppressive patriarchal figurations of femininity that dominate popular culture. Endorsing aesthetic dissonance as a political practice, women can reclaim their voices by producing a counter-discourse based on alternative fashion practices and disruptive self-imaginings. This is enacted by the unconventional fashion blogger Courtney Trop.
\end{abstract}

\section{Key Words}

Feminism; Gender; Social Media; Aesthetics; Capitalism

\section{Sommario/Contents}

1. The Visual Culture of Consumption

2. Consumer Capitalism and the Heteronormative Matrix

3. Encoding Oppression in Gender Imagery

4. Unveiling the Breach: The Fashion Industry

5. Political Resistance through Alternative Aesthetics

6. Demystifying Mythologies: Undoing Patriarchal Femininity on Social Media

7. Conclusion

Bibliography 


\section{Ocula ${ }^{25}$}

Vol 22, No 25 (June 2021) • DOI: 10.12977/ocula2021-8

Maria Chiara Caiazzo | Disruptive Tides

\section{The Visual Culture of Consumption}

Contemporary westernized capitalist societies are saturated with images, as late capitalist commodity production flowed into the formation of a parallel visual discourse. In no other form of society in history has there been such a concentration of images, such a density of visual messages (Berger 1972: 129), as capitalism has shifted emphasis «from production to reproduction, to the endless reduplication of signs, images and simulations» (Featherstone 1990: 7). The proliferation of visual languages linked to advertising campaigns was responsible for producing and reproducing new meanings. Images have a sharp social undertone which envelops individual and collective experiences, influencing how specific imageries are generated, established, and transformed (Marzo and Meo 2013: 5). Baudrillard (1970) observed that consumption entails the active manipulation of signs, which results in an «increasing salience of the production of symbolic goods, images and information» (Featherstone 1990: 14). Everyday consumption is always complemented by «a wider range of symbolic goods and experiences produced by the culture industries» (Featherstone 1990: 16). That is how, over the past few decades, capitalist commodity production has created and propagated the culture of consumption. Considering the cultural forms of commodities is essential to understand that capitalism «is as much a semiotic as an economic system» (Solomon-Godeau 1996: 114), one that uses publicity to propagate through images society's belief in itself (Berger 1972: 139). Such a belief is then absorbed into our own individual belief systems, which are shaped by environmental factors, experiences, and varying representations (Mróz 2016: 136).

The overproduction of signs and images implicated into capitalist endeavors demonstrates that commodities have increasingly given rise to meaning-making processes that went beyond the materiality of production (McRobbie 1997: 77), metamorphosing into social signs that produce meanings as well as energy (Hall 1989: 131). These images have a strong aesthetic power which comes to shape the social structure (Mróz 2016: 139), as material culture participates in the larger process of development of any possible subjectivity (Borgerson 2005: 442). Intended as a social and historical institution, imagery is the sphere that contains all the material and immaterial products that construct social life, making it possible (Marzo and Meo 2013: 7). Consumer acts are never neutral because consumer culture shapes our experience as individuals and collectivities, molding our identities and determining our place in society (Featherstone 1990: 12). In forming our identity, we must negotiate with the proliferation of signs in the built environment and urban fabric (ivi: 16). Therefore, identity is strongly mediated by images provided by the mass culture, to the point that it becomes «a theatrical presentation of the self» (Damean 2006: 89) aware of its state of "permanent visibility» (ivi: 91). Marked by an incessant flow of images and texts circulating into a new economy of the sign, our surrounding environment is constantly shifting. Despite being persistent, pervasive, and widely accepted, the reality constructed by the controlling images produced by capitalism is neither permanent nor irreplace- 


\section{Ocula ${ }^{25}$}

Vol 22, No 25 (June 2021) • DOI: 10.12977/ocula2021-8

Maria Chiara Caiazzo | Disruptive Tides

able, as «meanings are discursively constructed and are constantly in flux, as reality is an arena of contestation for particular ways of constructing how we see the world» (Sandlin and Maudlin 2012: 189). This instability makes way to new possibilities of being and becoming, as «our external identity and internal sense of self are imaginary constructs or working hypotheses subject to constant reform» (Belk 2013: 479). Indeed, nowadays, social identities have become flexible, mobile, and complex, marked by fluidity, segmentation, and hybridity (Gill and Scharff 2011: 299, 303).

This flexibility was eased by technological and digital developments which, through internet and social media, enabled the opening of new spaces of interaction and self-fashioning. The term "new media" was coined to label new digital instruments and computer networks that elicited the shift towards mass communication (Cosenza 2014: 4). Advances in communication technology and new media generated an "ecstasy of communication" (Baudrillard 1985) prompted by the sheer speed, intensity and extensiveness of virtual interrelational networks. The distribution of images, representations, and aestheticizations created by culture was significantly sped up, while also disclosing new possibilities of performing and aestheticizing the body (Mróz 2016: 138). Thanks to the immediacy of communication technologies, these plurified images and representations are also immediately accessible and available to a broad public (ivi: 143). Digital culture offers and spreads a wide range of alternative aesthetics and cultural texts. Today, social reality is partly extended to the digital world, and it is entangled in networks of hypercommunication. We live in a world of incessant image-making, meaning-making and mass communications where the media are an integral and fundamental part of social reality (McRobbie 1994: 203). The latter «is relayed to us through [...] language, communication and imagery» (ivi: 211), thereby social meanings are representations constructed across different types of media forms and channels. Damean observes that «media are efficient means for disseminating the dominant discourse of power and for disguising it into a matter of "common sense"» (2006: 90). This naturalistic fallacy polices the borders of social hierarchies. It regulates what is permissible, which images are acceptable or excluded, banning inappropriate visualizations, and presenting itself as unquestionable by condemning any alternative order of shared imagination (Mróz 2016: 142, 147). Essentially fluid, meaning practices are fixed within the paradigms of dominant imagined hierarchies, that are those established by patriarchal consumer capitalism. Then, aesthetic figurations control mobility in a sort of surveillance apparatus aimed at excluding those who do not fit into the images proposed, and need to be "normalized" through a series of practices of self-surveillance and self-control (Damean 2006: 91).

\section{Consumer Capitalism and the Heteronormative Matrix}

Engaging in various sites of consumption, «we learn particular gendered, raced and class consumer subjectivities» (Sandlin and Maudlin 2012: 176) that mold us as consuming subjects. Producing and selling «commodified expres- 


\section{Ocula ${ }^{25}$}

Vol 22, No 25 (June 2021) • DOI: 10.12977/ocula2021-8

Maria Chiara Caiazzo | Disruptive Tides

sions of selfhood» (Gill and Scharff 2011: 296), consumer capitalism also forges its consuming subjects as gendered subjects. Gendering involves an endless negotiation of power, privilege and embodiment (ivi: 309) that is sustained by the ideological norm of heterosexuality and binary gender (McRobbie 1994: 203). Indeed, the media has become the key site for defining codes of sexual conduct, casting judgement and establishing the rules of play (McRobbie 2009: 354). Specifically, gender is significant to the perpetuation of consumer capitalism because of the culturally and socially constructed gender roles we play as women and men in the context of consumer culture (Scanlon 2000: 1). For instance, in advertisements, male and female bodies are sexualized and constructed as objects of a voyeuristic pleasure that is linked to the eroticization of commodities (Solomon-Godeau 1996: 116-117). Commodities carry and produce meanings that police the borders of social and sexual difference (Roberts 1998: 841), therefore they reproduce asymmetrical power relations between men and women.

Consumption becomes «a context in which female roles are performed, challenged and legitimized» (Sandlin and Maudlin 2012: 176), albeit in different ways. Broadly speaking, the gendered construction of consumer subjects results in the suggested dichotomy of women as shoppers and men as producers (ivi: 178). This dichotomy reflects the asymmetrical distribution of visual power individuated by Berger, who emphasized that «men act and women appear. Men look at women. Women watch themselves being looked at» (Berger 1972: 47). The controlling images produced by patriarchal consumer capitalism posit women as «object(s) of vision» (ibidem) so that, since earliest childhood, women are taught to continually control their looks as their own sense of self is «supplanted by a sense of being appreciated as herself by another» (ivi: 46). Berger suggests that the social presence of a woman corresponds to an image (ivi: 45). This image, divorced from any real referent, represents woman-as-image rather than image-of woman (Roberts 1998: 828) and is aligned with «a condition of exaggerated specularity» (ivi: 829 ) that reduces woman to a sight. Furthermore, woman-as-image is mirrored by the idea of woman-as-body: as women, «we do not have bodies, but we are our bodies» (Agnihotri Gupta and Richters 2008: 246). Being reduced to their bodies and appearances, women in patriarchal cultures are judged for the way they look, which should always be in line with patriarchal standards. Woman-as-image must be shaped accordingly to established criteria of femininity that are subtly presented in popular culture in the form of images that women are meant to absorb, internalize, and reenact.

What emerges from this asymmetrical power dynamics is that, in consumer culture, woman is «tied to her place as bearer, not maker, of meaning» (Mulvey 1989: 15). The ideal female figure is styled according to specific constellations of heteronormative desire and fantasies about femininity (Mulvey 1989: 19; Roberts 1998: 827). The image world of mass cultural forms still operates to police the borders of female sexuality and womanhood, promoting one dominating vision to which women must abide (Meyers 2002: 27). As a result, «the hyper culture of commercial sexuality» (McRobbie 2009: 356) 


\section{Ocula ${ }^{25}$}

Vol 22, No 25 (June 2021) • DOI: 10.12977/ocula2021-8

Maria Chiara Caiazzo | Disruptive Tides

prompted by new media is an exclusionary mechanism that completely disregards the fluidity of gender structures and meaning practices (Gill and Scharff 2011: 152). This uniformity imposed on bodies is an act of violence rooted into the restricting frames of masculinist domination and compulsory heterosexuality (McRobbie 1994: 69; Butler 1990: 180).

\section{Encoding Oppression in Gender Imagery}

Patriarchal consumer capitalism is one of the cultural mechanisms whereby "we become the gendered, raced, and sexual beings that we are» (Haslanger 1995: 95). Revealing the artificiality of identity formation is important because «the deep contingency of such categories of identity and their associated patterns of behavior has significant political force» (ibidem). Liberal societies generate coherent identities through the matrix of coherent gender norms. Gender reality is fabricated as an interior essence, while it is an effect and function of a public and social discourse (Butler 1990: 23, 173). The gendered body is a source of oppression, as it is subject to the normalizing politics of self-surveillance, control, and complacency to specific standards (Damean 2006: 91). Berger argued that, when we see, we are not just looking, but «we are reading the language of images» (Berger 1972: 45). This act of reading unfolds cultural texts that are rife with patriarchal symbolisms, whose aesthetics presents a strong oppressive force aimed at endlessly reproducing conventional binary gender norms and the subordination of women.

The power of master narratives lies in their subtle mode of operation. Subliminally absorbed by us, these dominant paradigms shape our worldview and influence the way we enact our lives, and are thus reproduced in countless manners (Meyers 2002: 26; Sandlin and Maudlin 2012: 177). Notwithstanding its lurking character, the internalization of master narratives has a pervasive and violent impact on identity-formation processes. Within patriarchal discursive regimes, such as that of consumer culture, power relations are preserved and reproduced through the subtle presentation of a specific gender imagery. This is where the issue of internalized oppression emerges. As Meyers explains, «to internalize oppression is to incorporate inferiorizing material into the structure of the self - to see oneself as objectified» (Meyers 2002: 6). This “inferiorizing material” becomes embedded in women's cognitive and emotional infrastructures, and it constitutes the system of patriarchal figurations of womanhood (ivi: 27). Figurations of womanhood are culturally entrenched tropes, mythic tales, pictorial images defining and fossilizing toxic gender imagery that affects women's identities. The role of these figurations is to fossilize gender norms in culture by integrating them into the corpus of common sense (ivi: 25). In this way, gender norms are naturalized to the point that they remain unquestioned.

Figurations of womanhood are insidious because they convey a captivating and seductive gender imagery in an easily digestible and indelible form. They are marked by a vibrant immediacy and a potent emotional charge that facilitates their transmission and the retention of the messages they convey, hence 


\section{Ocula ${ }^{25}$}

Vol 22, No 25 (June 2021) • DOI: 10.12977/ocula2021-8

Maria Chiara Caiazzo | Disruptive Tides

their striking aesthetic power. That is because images are signs that are capable of building a dizzying game of perceptual and cognitive deception, that also determines the form of political discourse and entertainment culture (Corrain and Lancioni 2012: 215). The subtle potency of patriarchal figurations is enhanced by their ubiquity and adaptability (Meyers 2002: 26), further eased by mass communication technologies. Patriarchal figurations oppress women by subliminally forcing them to comply with modes of femininity that pose them as erotic tokens designed for visual consumption (Roberts 1998: 829). Late capitalism retains patriarchal interests in objectifying female sexuality, inculcating in women «the aesthetics of desirability» (Verkerk 2017: 155), resting on the assumption that female value is connected to being sexually attractive to men. This further reinforces the equation of women with their bodies, reducing them to pieces of flesh that must be beautified a certain way.

This patriarchal system of figurations, fueled and propagated by consumer capitalism, retains monopoly over gender discourse, furnishing the regnant interpretive and conceptual schemas, themes, and figurations whereby individual identities are formed and genderized (Meyers 2002: 24, 27). Women's identity formation processes are contaminated by oppressive patriarchal norms, responsible for complicating women's «epistemology of self-knowledge» (ivi: 24). The process whereby women get to know themselves and think about themselves is regulated by patriarchal norms, the default templates for women's self-portraits and self-narratives (ivi: 27). Drawing upon the dominant patriarchal system of figurations, women's self-imaginings «bespeak internalized oppression» (ivi: 28).

\section{Unveiling the Breach: The Fashion Industry}

Patriarchal consumer culture exerts control over women's representations and self-understanding, suffusing their voices and epistemologies, and haunting their choices (Meyers 2002: 28). Even in such a hostile environment, women possess some degree of agency, and it is essential that they learn how to use it to emancipate themselves (ivi: 4,5$)$. Emancipation starts from the delineation of a clearer conceptual framework in which to reframe women's agency and self-determination within patriarchal discursive regimes. Identity-construction is «an ongoing process of exercising a repertoire of agentic skills» which secure "a measure of self-understanding and self-determination» necessary to define oneself in one's own terms (ivi: 3, 24). Consumer capitalism institutionalizes male dominance and impedes women's ability to develop and exercise these agentic skills, essential to present their own acts of antagonism outside of patriarchal schemas. It is fundamental that women forge alternative discursive practices centered on the multiple ways of doing, enacting, and experiencing femininity through the reappropriation and resignification of dominant codings of the term (Meyers 2002: 28; Gill and Scharff 2011: 212, 304; McRobbie 1994: 70). Consumer capitalism is where patriarchal cultural texts are continually produced and transmitted. The exploitative and totalizing force of consumerism, with all the oppressive imagery 


\section{Ocula ${ }^{25}$}

Vol 22, No 25 (June 2021) • DOI: 10.12977/ocula2021-8

Maria Chiara Caiazzo | Disruptive Tides

it carries with it, can be countered by alternative modalities of engaging with its commodified signs. Consumption is an inescapable part of being a woman (Sandlin and Maudlin 2012: 176), hence it is inherently a feminist issue that can be converted into a site for political mobilization (McRobbie 1997: 84-85). Among the various sites of consumption, that of the fashion industry is certainly where the highest potentialities for rupture can be found. All women are «inevitably implicated in fashion» (Waggoner and Hallstein 2001: 29), so that is where the seeds of an emancipatory counter-discourse can bloom.

Traditionally an almost wholly feminized environment (McRobbie 1997: 84; Roberts 1998: 841; Slater, 1997: 82), fashion is a space where women construct and style their image, regulating their appearance in a relatively self-conscious manner. Clearly, «fashion matters and plays a significant role in constructing culturally appropriate forms of femininity» (Waggoner and Hallstein 2001: 29). Patriarchal consumerism encourages women to buy specific modes of femininity latently encoded in publicity. The signs constituting female consumer subjectivity liquefy into the ideal woman-as-image, drawing the contours of the desired presence that woman should occupy in societal contexts.

Fashion has an ambivalent relation to women as it poses the agency/constraint conundrum: women are positioned as both passive objects and active subjects of fashion. Smith discusses the tripartite relationship of women to their bodies, which is always mediated by cultural texts. The distance between women as subjects and their body as object is created by the textual images through which women become self-conscious about their body, worrying about whether it complies with normative patriarchal standards (Smith 1988: 50). These tend to alienate women from themselves and their bodies (Meyers 2002: 12). Smith's textual images correspond to Meyers' figurations, so they are essentially mediatic visual representations of womanhood that can be found in multiple sites of popular culture and consumption, for instance in television, magazines, and fashion displays. Moreover, fashion is constantly invested in the production of an ideal image of women's body that denies the markers of female reproductive capabilities - breasts and hips - and deprives women's bodies of their organic functions - such as menstruation (Shugart, Waggoner and Hallstein 2001: 203; Brewis et al. 2011).

Verkerk observes that «sexual objectification acts to shape women as both consumers with buying power and as consumable objects» (Verkerk 2017: 149). The discourse of fashion is a form of cultural domination that shapes women's subjectivity (Roberts 1998: 841), while depoliticizing female experience through the promotion of texts of enjoyment and relaxation (McRobbie 1997: 74; 2009, 359; Gill and Scharff 2011: 46). Women, especially young girls, establish an uncritical relation to dominant commercially produced sexual representations that make them, to some extent, complicit to patriarchal oppression (McRobbie 2009: 356). The recent commodification of feminist ideals has further problematized the already ambiguous relation between women and fashion. Female empowerment has been transformed into an extremely attractive commodity that «contributes to rearticulating dominant patriarchal and 


\section{Ocula ${ }^{25}$}

Vol 22, No 25 (June 2021) • DOI: 10.12977/ocula2021-8

Maria Chiara Caiazzo | Disruptive Tides

capitalist values, while not substantially disrupting power relations» (Riordan 2001: 282). As a result, «feminist values are appropriated in the name of reproducing the status quo» (Gill and Scharff 2011: 287), leaving the traditional gender order undisturbed. Promoting neoliberal values of self-improvement and personal freedom, patriarchal consumer capitalism encourages women to embark on projects of individualized self-definition and privatized self-expression, thus shaping a postfeminist identity that abides by the dreams of the neoliberal subject (ivi: 43-46, 281). A consequence of the commodification of emancipated femininity is the exaltation of a postfeminist politics based on self-definition rather than on a social and collective agenda for political action and resistance (ivi: 43, 49, 283). Hence, with the appropriation of a pseudo-feminist politics, consumer capitalism attempts to hinder the constitution of collective identities and political aggregations that, on a larger scale, can recalibrate and supplant its oppressive gender politics (ivi: 309).

\section{Political Resistance through Alternative Aesthetics}

Given the centrality of women in the sphere of visibility, an effective feminist counter-discourse must spring from the world of images. Emancipation must occur aesthetically because «art and aesthetic taste are powerful framers of self-image, social identity, and public values» (Korsmeyer 2004: 1). The image becomes the main locus for theoretical speculations, essential to develop effective resistance strategies (Corrain and Lancioni 2012: 224). Therefore, revolution occurs within the Dionysian dimension of the social world, that is characterized by a flux of collective energies that incorporate counter-imagery into daily life (Maffesoli 1990; Marzo and Meo 2013: 8). If figurations of womanhood operate through aesthetic patterns of visual pleasure, then women can deploy aesthetic dissonance as a political practice. Aesthetic dissonance is an experience that leads to a reformation of habits, behavior, values, and institutions a violation of aesthetic expectations (Mróz 2019: 6). Here, aesthetics and politics are inextricably linked. Aesthetics is concerned with general feeling and sensibility, in that it aims to produce a new perception of the world, creating a commitment to its transformation. In turn, politics is bound to an aesthetic and perceptual understanding because it is always engaged with seeing, hearing, and recognizing different subjects, experiences, tensions, and identities (Rancière 2010). The construction of a feminist counter-discourse must stem from a collected ability to share the aesthetic, the sensibilities, and the feelings of the group in question (Mróz 2019: 6); it must arrive at a renewed politico-aesthetic consciousness inscribed within a social process of participation that engages women in sociation rather than consumption (Stiegler 2011: 233). Capitalism functionalized the emotional and aesthetic dimension to make a consumer (Mróz 2019: 8), so it is necessary that women take up the aesthetic valence of fashion to restyle themselves.

The emancipatory potential of fashion lies in its parallelism with gender, and in its preponderance in orchestrating the performance of the gendered subject. Understood as «the tacit collective agreement to perform, produce, 


\section{Ocula ${ }^{25}$}

Vol 22, No 25 (June 2021) • DOI: 10.12977/ocula2021-8

Maria Chiara Caiazzo | Disruptive Tides

and sustain discrete and polar genders as cultural fictions» (Butler 1990: 173), gender is socially and culturally constituted through specific practices that are monopolized by patriarchal discourse. Fashion provides the costumes for the theatrical construction of the self. In order to perform gender properly, one must engage in a specific set of consumption habits and behaviors. By performing fashion in disruptive, unconventional ways, women can reclaim their voices. Hence, fashion's commodified cultural landscapes can act as a crucial site for the transgression of conventional gender identities, encouraging women to shape new, subversive selves (Roberts 1998: 843). As a performative consumption practice, fashion offers a space where women can act out the instability of gender identity, refashioning themselves as women through alternative aesthetics.

\section{Demystifying Mythologies: Undoing Patriarchal Femininity on Social Media}

The overarching capitalist system of surveillance must be countered by capillary networks of resistance. Resistance to systemic oppression must be channeled into circuits of transindividuation, with the aim to establish communicative bonds between women as the basis for a feminist political agenda (Braidotti 1992). The digital revolution enabled the creation of a web of interconnecting meanings, each with its own momentum, pacing, narrative structures, and accompanying images (McRobbie 1994: 207). Cultural and technological developments potentially make space for the representation of new constructions of sexuality and femininity (Gill and Scharff 2011: 203), as the digital world allows for «a greater repertoire of representing the body, sexuality, and gender» (Mróz 2016: 152). The subject is constructed performatively through the repetition of given signs and norms; subjectivity is produced within the processes of signification that construct the self, while agency is «located within the possibility of a variation on that repetition of norms» (Butler 1990: 145). Such a variation can easily occur in the digital realm as cyberspace offers countless sites for experimentation and reworlding, thus extending the identity project far beyond the body (Belk 2013: 486). The goal is to alter stable subjects of feminist discourse, that is, to reframe through difference and differential practices what it means to be a woman. As Butler states, «what women signify has been taken for granted too long [...] we have to instead break from the list of meanings and expand the possibilities of what it means to be a woman» (Butler 1992: 16). The hyperconnectivity of the digital world is a good starting point to renegotiate women's engagement with patriarchal consumer society. In conjunction with the political practice of aesthetic dissonance, hyperconnectivity and new media present a highly disruptive potential (Mróz 2019: 6). In particular, the accessibility and immediacy of social media. Fashion practices and social media find their most emblematic convergence in the figure of the fashion blogger who, through the daily display of their fashion practices, clearly define their position in relation to consumer capitalism. More often women than men, fashion bloggers usual- 


\section{Ocula ${ }^{25}$}

Vol 22, No 25 (June 2021) • DOI: 10.12977/ocula2021-8

Maria Chiara Caiazzo | Disruptive Tides

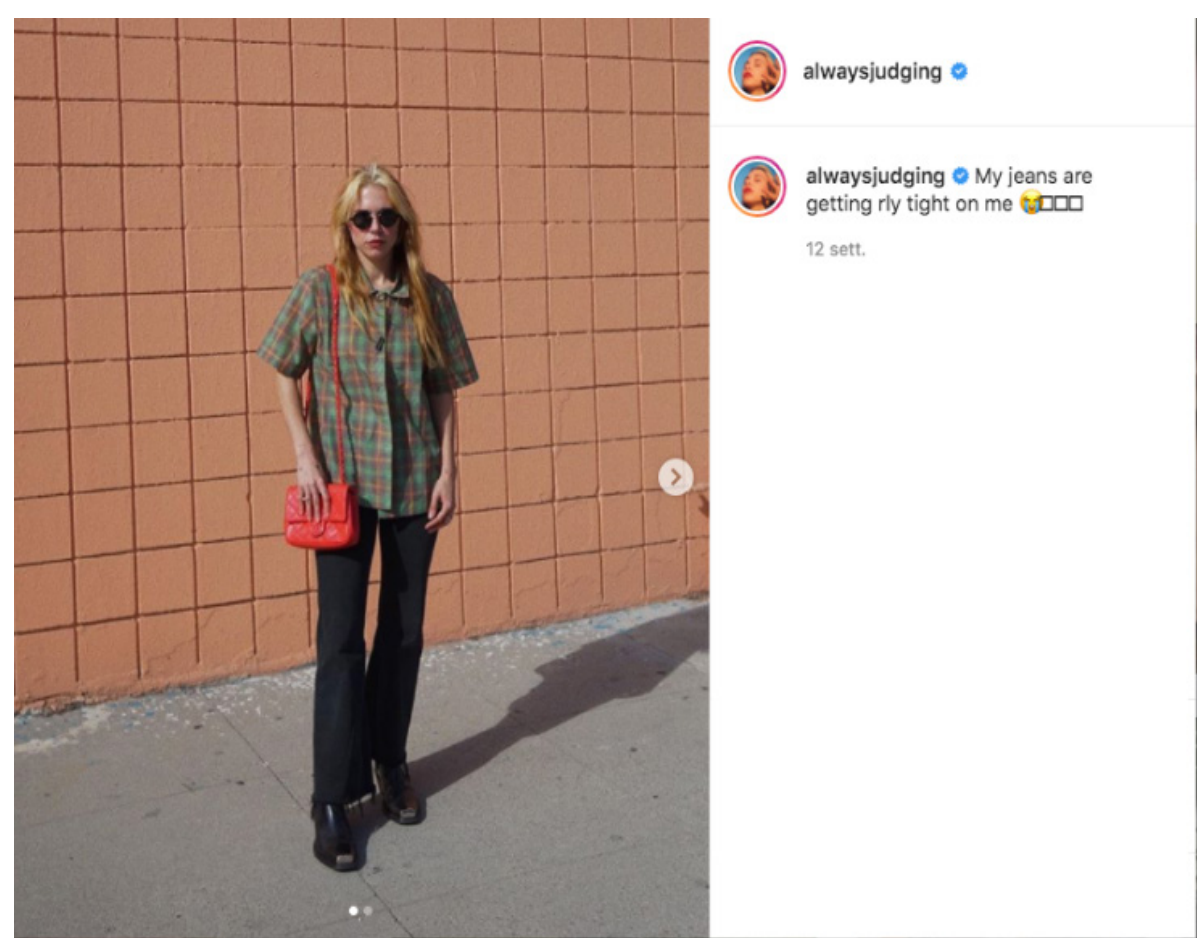

Figure 1. Courtney's androgynous look.

ly post on Instagram, a social network that is entirely based on images. In our social realities, whether virtual or not, women find themselves in a condition of "exaggerated specularity". An effective resistance strategy must negotiate with this state of permanent visibility.

Courtney Trop (@alwaysjudging) is a thirty-three-year-old American Instagram influencer who actively engages in counter-discursive practices with the effect of reformulating oppressive gendered cultural texts. Courtney identifies as a cis woman, a label that she is continually resignifying through her critical engagement with fashion and with her own self-representations. Courtney's engagement with fashion counters patriarchal capitalism both economically and culturally. She usually chooses ethical, sustainable, and environmentally conscious brands, promoting local shops, especially second-hand clothing. Her relationship with the fashion industry is mediated by her conscious practices that oppose fast fashion, and mass consumption. At the core of capitalism is an essentially patriarchal ideology that cannot only be questioned on a symbolic, cultural level. Practical action is also required. Additionally, mindful of patriarchal standards of femininity, Courtney purposely advances her own style. The latter does not reject conventional femininity in toto, but instead it incorporates conventionally feminine elements into a fluid mode that surpasses binary gender norms.

In figura 1, Courtney's glasses, shirt, and trousers are unisex, perhaps more assimilable to masculine clothes. However, the red purse and the heels are traditionally feminine garment, rife with that kind of femme fatale femininity 


\section{Ocula ${ }^{25}$}

Vol 22, No 25 (June 2021) • DOI: 10.12977/ocula2021-8

Maria Chiara Caiazzo | Disruptive Tides

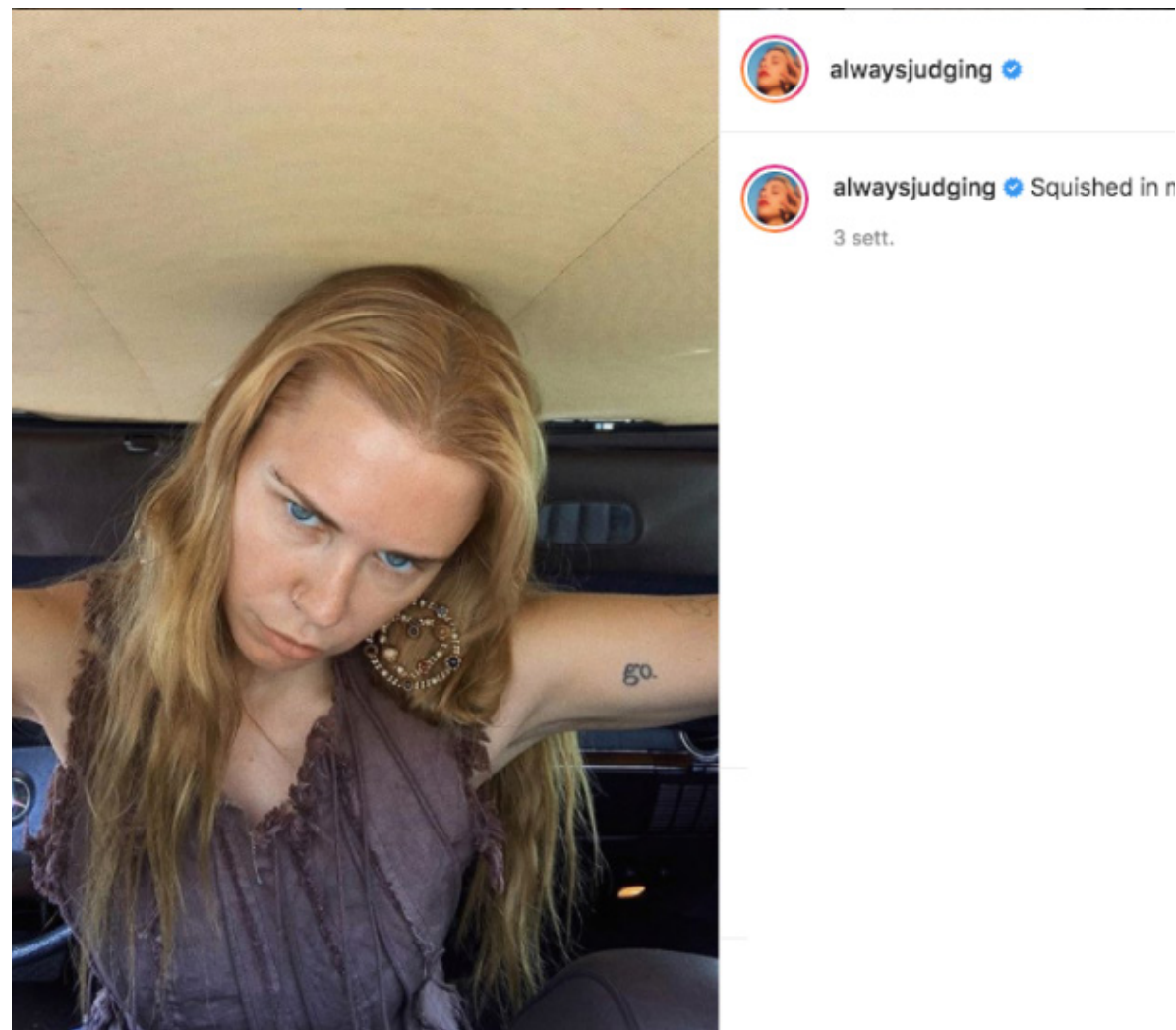

Figure 2. Courtney "squished" in her car.

that dominates popular culture. This coexistence of heterogeneous elements associated to two distinct genders is an example of aesthetic dissonance. Courtney displays her quasi-androgynous look in a clumsy, stiff posture without deigning the camera, and the observer, a smile. That of the refuse to smile is a recurring theme on her feed, an act that can be read as the enactment of Ahmed's killjoy manifesto. If patriarchal figurations promote a socially constructed happiness to which women must conform, then it is women's duty to kill joy as an act of resistance. There can be joy in killing joy, namely the joy resulting from countering oppressive patriarchal discourse (Ahmed 2017).

Courtney's captions are complementary to her pictures, as they articulate a resignification of femininity with words instead of visual elements. Here, she complains that her jeans are getting really tight on her. The way the sentence is phrased denotes that she is comfortable with her weight gain. The latter is forbidden in patriarchal cultural regimes, where women are supposed to constantly monitor their body, making sure it is always the "right size". The attack to diet culture is implicit, as Courtney seems to suggest that the solution to this problem will be to get a new pair of jeans. The need to lose weight or to exercise more is never expressed. Finally, shedding light on weight gain, she underscores the realness of women's bodies. These are natural, organic; they are subject to change over time, and such a change is an integral part of female experience and, as such, it must not be denied or rejected. 


\section{Ocula ${ }^{25}$}

Vol 22, No 25 (June 2021) • DOI: 10.12977/ocula2021-8

Maria Chiara Caiazzo | Disruptive Tides

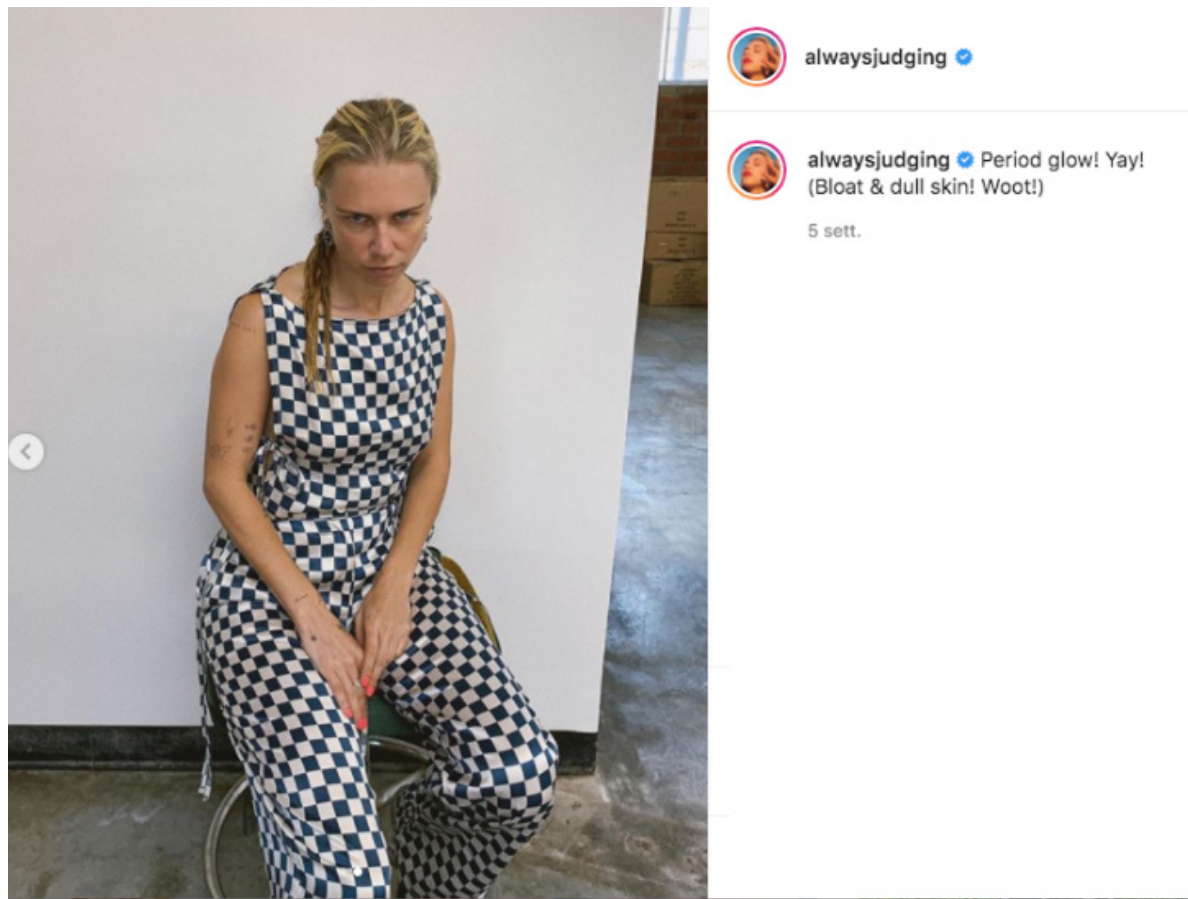

Figure 3. Period glow.

The subversiveness of Courtney's self-representations stems from her position as object of vision in the digital panopticon of new media. This state of permanent visibility has been induced to women to grant the automatic effects of power, whereby women are supposed to act as if a masculine observer were permanently watching them (Damean 2006: 91). Courtney turns this state of permanent visibility to her favor, rigidly controlling her self-display. Always grumpy, clumsy, serious. Courtney looks at the camera fiercely and intimidatingly (fig. 2). There is no sense of passivity in her gaze, no mercy, no meekness. Despite being observed, Courtney does not merely appear. Rather, she acts in and through her own appearance and self-display, to the extent that she renegotiates the power of the gaze. She stares back. The condition of exaggerated specularity promises a subversive political effect. Courtney establishes an interesting visual interaction with her virtual spectatorship, as she seems to be looking at the eye that is observing her. Controlled visibility, the power of knowing what you are showing, presents an immense aesthetic force. Staring back is a political act that makes Courtney the real controller of the gaze. Her intimidating self-presentation is complemented by the tattoo on her arm, the imperative "go." that, in conjunction with the image, further exemplifies her status as a feminist killjoy.

The caption is emblematic for its word choice: "squished in my car". The word squished is onomatopoeic, and recalls something gelatinous and slimy, far from any sexy or sexual connotations.

To express her own experience of femininity, Courtney stresses the organicity of the female body as a counter-discourse to dominant cultural texts of objec- 


\section{Ocula ${ }^{25}$}

Vol 22, No 25 (June 2021) • DOI: 10.12977/ocula2021-8

Maria Chiara Caiazzo | Disruptive Tides

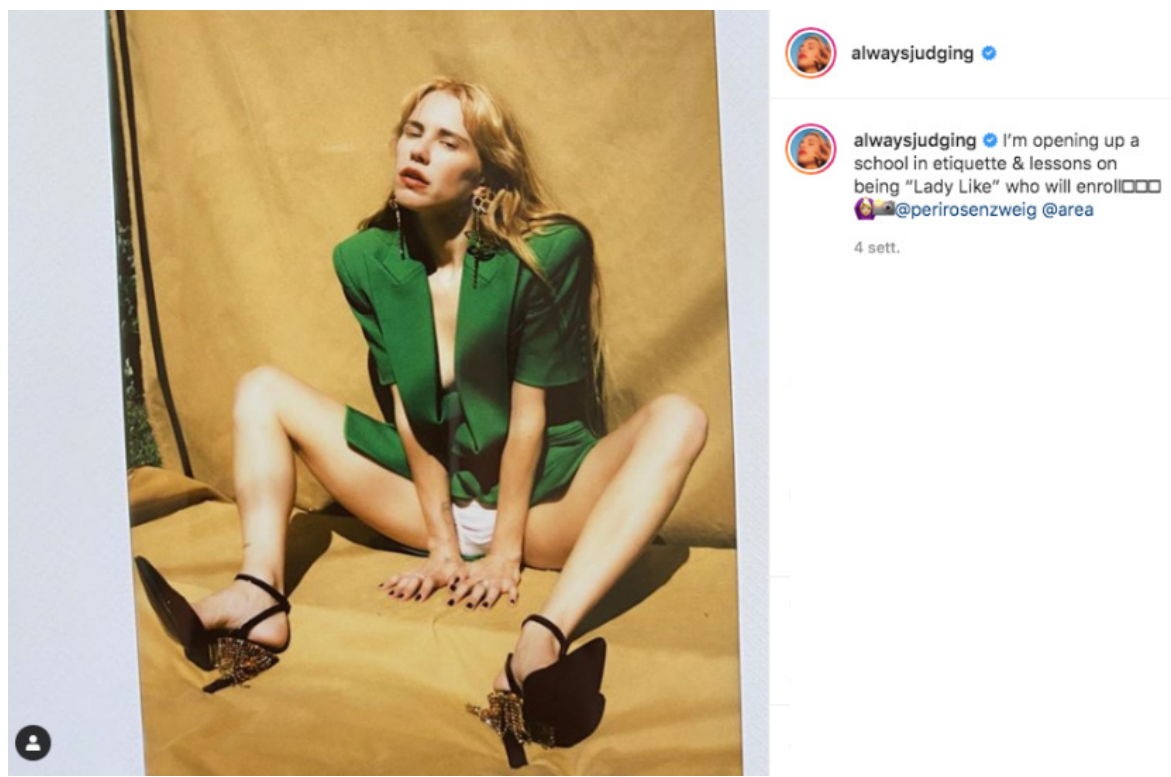

Figure 4. Challenging "Lady Like" conventions.

tivation and sexualization. In figura 3 , she is sitting on a stool in a deliberately awkward pose. Her hair is greasy, her face looks annoyed, staring directly at the camera. Once again, she stares back, in full control of the gaze. Reclaiming the power of the scrutinizing eye, the dynamics between observing subject and observed object is disrupted: it is now the observer to feel observed. Her look is unfriendly, merciless; it kills joy by denying visual pleasure to the spectator.

In the caption, Courtney breaks the period stigma. Patriarchal culture denies the organic, biological functions of the female body. Period is a taboo, sometimes even subject to censorship on social media. Reclaiming the naturalness of her body, Courtney puts period in the spotlight in the counter-figurations she is producing. Ironically, she talks about "period glow", and then she emphasizes bloat and dull skin, both unacceptable in patriarchal consumer society. Cosmetic and pharmaceutical industries insist on finding remedies to them, parallel to the demonization of cellulitis and stretch marks. Women are meant to control their appearance all the time and, as a response, Courtney draws attention to these small things that are deemed as imperfections, accepting and promoting them as a natural part of her experience as a woman.

An explicit disruption of conventional gender norms is articulated in figura 4. Unlike the other pictures, this one was taken for an advertising campaign. Yet, she still maintains her trademark as an unconventional model. Reference to dominant femininity is clear: dangle earrings, make up, long loose hair, a low-cut blazer and a pair of elegant heels. Aesthetic dissonance is prompted by two elements, namely the bottoms and the pose. The sexualization of femininity also centers on lingerie, as women are meant to wear sexy, lacy underwear that enhance their figure. By contrast, Courtney is wearing big, white, simple underpants. This contributes to the deglamorization of fashion, characteristic of her approach to the industry. Similarly, her pose breaks the norms of con- 


\section{Ocula ${ }^{25}$}

Vol 22, No 25 (June 2021) • DOI: 10.12977/ocula2021-8

Maria Chiara Caiazzo | Disruptive Tides

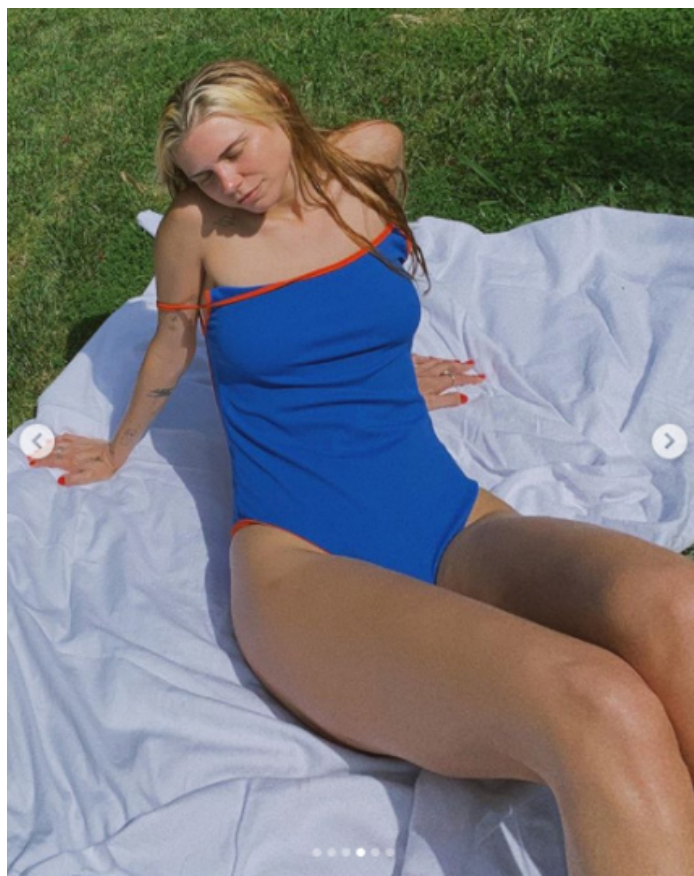

alwaysjudging 0

alwaysjudging $\odot$ A series of photos

distorted I've never used face

tune to edit my body but maybe l'll

download it now so I can make things

look weird and wonky fs

Figure 5. Distorted sunbathing.

ventional femininity, which requires women to be composed, delicate, and subtle. Instead, Courtney's legs are spread wide open, an act that is only permissible to men. That is why, in the caption, Courtney ironically underscores her attitude towards etiquette and "Lady Like" conventions. Finally, her pose with legs wide open is not to be read as availability, a sort of sexual invitation. Contrarily, her hands in the front endow the pose with a sense of being in a defensive yet comfortable position, thus conveying a sexuality that is for her and not for others.

In the context of online display, we increasingly see the construction of a body-as-performance relationship that becomes evident in a range of practices that restyle the body, emphasizing the malleability of its presentations (Waskul 2003: 93). This happens especially because digital self-presentation is marked by digitally altered photographs (Belk 2013: 490). The images produced by the advertising industry are never raw, but they undergo a process of post-production through photo-editing softwares able to smooth skin and reshape the body. Therefore, patriarchal figurations propose unreal standards of femininity, presenting an image of the female body that is achieved through technical devices. It is common that fashion bloggers too, on Instagram, edit their photos before posting them so as to comply with normative femininity. Courtney does not use filters or aftereffects, and when she does, she does so in a radically subversive manner (fig. 5).

While she does not usually display her body, preferring baggy, flamboyant, vintage garments that hide her silhouette, the moment Courtney posts a picture in a swimsuit she does so in an ironic way. Sunbathing, Courtney keeps resisting the male gaze by playing with the very process of subjection 


\section{Ocula ${ }^{25}$}

Vol 22, No 25 (June 2021) • DOI: 10.12977/ocula2021-8

Maria Chiara Caiazzo | Disruptive Tides

that forges women as sights (McRobbie 1994: 70). Self-display is extended beyond the body, whose malleability is articulated through distortion. Courtney adopts a strategy of unsettlement that embraces the idea of difference and hybridity (ivi: 65). She causes unsettlement by shaping her image through aesthetic dissonance, thus presenting an alternative self-fashioning that is in stark contrast to patriarchal figurations. For instance, she enlarges her legs out of proportion in relation to the rest of the body, which she distorts by playing with widths and lengths, thus creating a series of self-portraits in which her figure is meticulously distorted by her. As a result, the real proportions of her body remain unknown, and this challenges consumer culture's obsession with size and with the mathematical regulation of the ideal proportions of women's bodies. If patriarchal figurations want women's legs to be slim, then Courtney will make them bigger on purpose. Hence, Courtney's engagement with bodily display on Instagram is mindful of a condition of exaggerated specularity, and of all the attributes of conventional femininity that, one by one, she breaks by offering her alternative self-presentations.

Finally, it is worth noticing her choice of adjectives in the caption: she wants to make things look "weird" and "wonky". Instability and eccentricity are the filters whereby she wants to present her self-displays. This final image, complemented by the caption, represents the peak of Courtney's rejection of patriarchal normativity, the ultimate statement that it is she who is in control of what is seen, and how.

\section{Conclusion}

Consumer capitalism is responsible for producing patriarchal figurations of womanhood, thus perpetuating oppressive gender imagery. These figurations police the female body and psyche, operating both externally and internally, while also regulating its social positioning (Damean 2006: 91). The interaction between individual and collective imageries triggers a social dynamic that is either oriented towards variation or radical change (Marzo and Meo 2010). For this reason, a vital feminist objective would be to replace patriarchal figurations with emancipatory counter-figurations (Meyers 2002: 26) that can account for the flexible and wide spectrum of feminine identities and experiences. To gain this kind of authenticity, it is necessary to employ new forms and words that are outside of conventional patriarchal schemes (Zanardo 2010: 137). It is about highlighting exposures to different cultural representations of femininity that can oppose dominant, subjugating cultural texts. The creation of an effective feminist counter-discourse, promoting alternative images and aesthetics, requires collective action, and the establishment of close bonds and networks of communication among women. As an inherently social space, cyberspace allows for a viral spreading of countless possible self-imaginings (Belk 2013: 487). Feminist resistance must move within the networks of digital space. The strength of feminism lies in its ability to create discourse, to dispute, to negotiate boundaries and barriers in order to make space for alternative representations (McRobbie 1994: 72). Intertwined 


\section{Ocula ${ }^{25}$}

Vol 22, No 25 (June 2021) • DOI: 10.12977/ocula2021-8

Maria Chiara Caiazzo | Disruptive Tides

with politics, aesthetics here plays a crucial role in shaping alternative cultural texts, as women can actively engage in aesthetic dissonance as a political practice to put forward their disruptive antagonisms.

Courtney Trop enacts this kind of politico-aesthetic resistance not only by challenging oppressive patriarchal norms, but also by actively exerting her agency as a subject in the process of identity-formation. She preserves her own experience of femininity, constantly articulating what womanhood means to her. Presenting her own figurations, her own aesthetics, and challenging patriarchal stigmas, Courtney resignifies femininity in an original and ironic way, promoting an image that is based on the naturalness and organicity of women's bodies, and on attitudes of confidence and intimidation. She turns her state of exaggerated specularity to her own advantage by refusing to comply with patriarchal figurations. She behaves as if she was constantly being watched by a scrutinizing male observer. Yet, instead of abiding by the norms, she purposely breaks them. Notwithstanding her feminized role as a fashion blogger, Courtney exploits what is expected of her and constantly eludes it through controlled forms of visibility. These put her in a position of visual power, renegotiating the terms of Berger's equation, and provide a much more empowering position than submitting to traditional forms of the gaze (White 2006: 72). This demonstrates that politics also resides in cultural texts, whose aesthetic power can have an oppressive or a liberating force. An emancipatory feminist counter-discourse must spring from here.

\section{Bibliography}

Agnihotri Gupta, Jyotsna; Richters, Annemiek

2008 "Embodied Subjects and Fragmented Objects: Women's Bodies, Assisted Reproduction Technologies and the Right to Self-Determination”, Bioethical Inquiry, 5, pp. 239-249.

Ahmed, Sara

2017 Living a Feminist Life, Durham, Duke University Press.

Baudrillard, Jean

1970 La société de consommation, Paris, Gallimard.

1985 "The Ecstasy of Communication" in Foster, Hal (ed.), Postmodern Culture, London, Pluto Press.

Belk, Russell W.

2013 "Extended Self in a Digital World", Journal of Consumer Research, 40, pp. 477-500.

Berger, John

1972 Ways of Seeing, London, Penguin.

Borgerson, Janet

2005 "Materiality, Agency, and the Constitution of Consuming Subjects", Advances in Consumer Research, 32, pp. 439-443. 


\section{Ocula ${ }^{25}$}

Vol 22, No 25 (June 2021) • DOI: 10.12977/ocula2021-8

Maria Chiara Caiazzo | Disruptive Tides

Braidotti, Rosi

1992 "On the Feminist Female Subject or from She-self to She-other", in Bock, Gisela; James, Susan (eds.), Beyond Equality and Difference: Citizenship, Feminist Politics and Female Subjectivity, London, Routledge.

Brewis, Alexandra A. et al.

2011 "Body Norms and Fat Stigma in Global Perspective", Current Anthropology, 52, pp. 269-276.

Butler, Judith

1990 Gender Trouble: Feminism and the Subversion of Identity, New York, Routledge.

1992 “Contingent Foundations: Feminism and the Question of 'Postmodernism”, in Butler, Judith; Scott, Joan W. (eds.), Feminists Theorize the Political, London, Routledge.

Corrain, Lucia; Lancioni, Tarcisio

2012 "Geometrie del senso. Ripensare la semiotica dell'immagine a partire da $L a$ macchina della pittura”, Galaxia, 24, pp. 214-230.

Cosenza, Giovanna

2014 Introduzione alla semiotica dei nuovi media, Roma-Bari, Laterza.

Damean, Diana

2006 "Media and Gender: Constructing Feminine Identities in a Postmodern Culture”, Journal for the Study of Religions and Ideologies, 5, pp. 89-94.

Featherstone, Mike

1990 "Perspectives on Consumer Culture", Sociology, 24, pp. 5-22.

Gill, Rosalind; Scharff, Christina (eds.)

2011 New Femininities: Postfeminism, Neoliberalism and Subjectivity, Basingstoke, Palgrave Macmillan.

Hall, Stuart

1989 "The Meaning of New Times" in Hall, Stuart and Jacques, Martin (eds.), New Times: The Changing Face of Politics in the 1990s, London, Lawrence \& Wishart.

Haslanger, Sally

1995 “Ontology and Social Construction”, Philosophical Topics, 23, pp. 95-125.

Korsmeyer, Carolyn

2004 Gender and Aesthetics: An Introduction, London, Routledge.

Maffesoli, Michel

1990 L'ombra di Dioniso. Per una sociologia delle passioni, Milano, Garzanti.

Marzo, Pier Luca; Meo, Milena

2010 L'eterno e l'effimero. Contributi per una lettura altra del mutamento sociale, Roma, Aracne.

2013 “Cartografie dell’immaginario”, Im@go, 1, pp.4-17.

McRobbie, Angela

1994 Postmodernism and Popular Culture, London, Routledge. 


\section{Ocula ${ }^{25}$}

Vol 22, No 25 (June 2021) • DOI: 10.12977/ocula2021-8

Maria Chiara Caiazzo | Disruptive Tides

1997 "Bridging the Gap: Feminism, Fashion and Consumption", Feminist Review, 55, pp. 73-89.

2009 "Post-Feminism and Popular Culture" in Thornham, Sue et al. (eds.), Media Studies: A Reader, Edinburgh, Edinburgh University Press.

Meyers, Diana T.

2002 Gender in the Mirror: Cultural Imagery and Women's Agency, Oxford, Oxford University Press.

Mróz, Adrian

2016 "Imagined Hierarchies as Conditionals of Gender in Aesthetics", Estetyka I Kryryka, 41, 2, pp. 135-154.

2019 "Aesthetic Dissonance: On Behavior, Values, and Experience through New Media”, Hybris, 47, pp. 1-21.

Mulvey, Laura

1989 Visual and Other Pleasures, New York, Palgrave Macmillan, 2009².

Rancière, Jacques (ed.)

2010 Dissensus: On Politics and Aesthetics, London, Continuum.

Riordan, Ellen

2001 "Commodified Agents and Empowered Girls: Consuming and Producing Feminism”, Journal of Communication Inquiry, 25, pp. 279-297.

Roberts, Mary Louise

1998 "Gender, Consumption, and Commodity Culture", The American Historical Review, 103, pp. 817-844.

Sandlin, Jennifer A.; Maudlin, Julie G.

2012 "Consuming Pedagogies: Controlling Images of Women as Consumers in Popular Culture”, Journal of Consumer Culture, 12, pp. 175-194.

Scanlon, Jennifer (ed.)

2000 The Gender and Consumer Culture Reader, New York, New York University Press.

Shugart, Helene; Waggoner, Catherine E.; Hallstein, Lynn O’Brien

2001 "Mediating Third-wave Feminism: Appropriation as Postmodern Media Practice”, Critical Studies in Media Communication, 18, pp. 194-210.

Slater, Don

1997 Consumer Culture and Modernity, Cambridge, Polity Press.

Smith, Dorothy E.

1988 "Femininity as Discourse", in Roman, Leslie G.; Christan-Smith, Linda K. (eds.), Becoming Feminine: The Politics of Popular Culture, New York, Falmer.

Solomon-Godeau, Abigail

1996 "The Other Side of Venus: The Visual Economy of Feminine Display", in de Grazia, Victoria; Furlough, Ellen (eds.), The Sex of Things: Gender and Consumption in Historical Perspective, Berkley, University of California Press. 


\section{Ocula ${ }^{25}$}

Vol 22, No 25 (June 2021) • DOI: 10.12977/ocula2021-8

Maria Chiara Caiazzo | Disruptive Tides

Stiegler, Bernard

2011 "The Tongue of the Eye: What 'Art History' Means", in Khalip, Jacques; Mitchell, Robert (eds.), Releasing the Image: From Literature to New Media, Stanford, Stanford University Press.

Verkerk, Willow

2017 "Reification, Sexual Objectification, and Feminist Activism", in Gandesha, Samir; Hartle, Johan F. (ed.), The Spell of Capital: Reification and Spectacle, Amsterdam, Amsterdam University Press.

Waggoner, Catherine; Hallstein, Lynn O'Brien

2001 "Feminist Ideologies Meet Fashionable Bodies: Managing the Agency/ Constraint Conundrum”, Text and Performance Quarterly, 21, pp. 26-46.

Waskul, Dennis D.

2003 Self-Games and Body-Play: Personhood in Online Chat and Cybersex, New York, Peter Lang.

White, Michele

2006 The Body and the Screen: Theories of Internet Spectatorship, Cambridge (MA), The MIT Press.

Zanardo, Lorella

2010 Il corpo delle donne, Milano, Feltrinelli.

Maria Chiara Caiazzo Completed a BA (Hons) in Comparative Literature at King's College London, presenting a thesis in Narratology and Feminist Theory. She obtained a Master of Arts in Political Philosophy at the Universitat Pompeu Fabra, where her thesis on Aesthetics and Politics was awarded the matrícula de honor. Thanks to merit-based scholarships, she spent one semester at the University of North Carolina at Chapel Hill and attended Summer Schools at the Vrije Universiteit Amsterdam and Utrecht University. Currently, she is a fellow researcher at the Italian Institute for Philosophical Studies in Naples, and she is studying Philosophy at the University of Naples "Federico II". Her research is centered on the points of convergence between aesthetics and politics, with particular attention to the themes of emergency, gender studies, and collective action. She works as Alumni ambassador for King's College London, and as international ambassador for Vrije Universiteit Amsterdam. She is dedicated to photography, videography, and digital art. She fluently speaks Italian, English, French and Spanish, and she translates from Latin and Ancient Greek. 


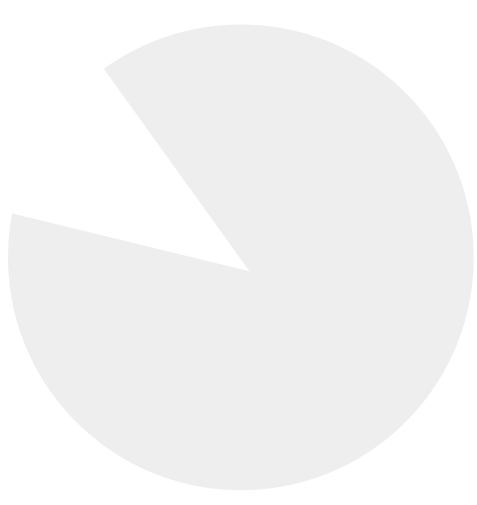

